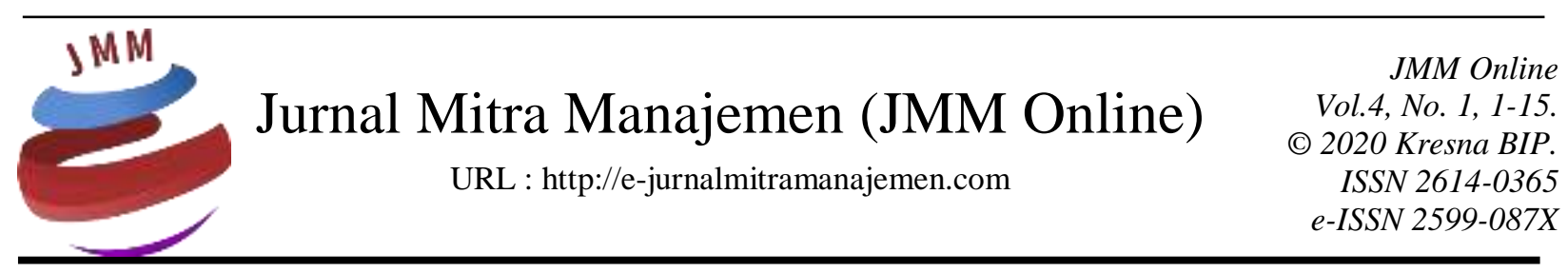

\title{
PENGARUH KUALITAS WEBSITE TRAVELOKA TERHADAP SIKAP PENGGUNA DAN MINAT BERPARTISIPASI DALAM ONLINE CO-CREATION
}

\author{
Renata Callista $^{1)}$, Osa Omar Sharif ${ }^{2)}$ \\ Universitas Telkom
}

\section{INFORMASI ARTIKEL}

Dikirim : 01 Januari 2020

Revisi pertama : 09 Januari 2020

Diterima : 13 Januari 2020

Tersedia online : 31 Januari 2020

Kata Kunci : Co-Creation, Ease of Use, Interactivity, Kualitas Website, Traveloka, Sikap, Web Design

\section{Email :}

renatacallista@student.telkomuniversity. ac.id ${ }^{1)}$

osaomarsharif@telkomuniversity.ac.id ${ }^{2)}$

\section{ABSTRAK}

Tujuan dari penelitian ini yaitu untuk mengetahui bagaimana pengaruh kualitas website terhadap sikap pengunjung dan minat berpartisipasi dalam online cocreation pada website Traveloka sebagai e-commerce terpopuler di Indonesia dengan jumlah pengunjung website tertinggi. Metode yang digunakan dalam penelitian ini adalah metode kuantitatif dengan mengumpulkan data hasil kuesioner menggunakan sampel sebanyak 412 responden dengan teknik random sampling dari populasi pengunjung website Traveloka yang pernah mengunjungi dan melakukan transaksi di website Traveloka yang dianalisis menggunakan teknik analisis jalur (path analysis) dan diolah menggunakan software statistik SPSS 26. Hasil dari penelitian ini menunjukkan bahwa terdapat pengaruh antara kualitas website terhadap sikap pengguna melalui variabel ease of use, interactivity, dan web design, terdapat pengaruh antara sikap pengguna terhadap minat online co-creation, serta terdapat pengaruh antara kualitas website terhadap cocreation melalui variabel interactivity dan web design. 


\section{PENDAHULUAN}

\section{Latar Belakang}

Perkembangan era digital yang diikuti dengan banyaknya jumlah pengguna internet menciptakan peluang salah satunya dalam dunia bisnis, yang ditandai dengan munculnya berbagai macam e-commerce di dunia khususnya di Indonesia. Peluang tersebut dapat dimanfaatkan secara optimal untuk memenuhi kebutuhan traveling. Salah satu $e$-commerce yang cukup terkenal beberapa tahun ke belakang hingga tahun 2019 adalah Traveloka. Website Traveloka berhasil meraih angka pengunjung tertinggi sebagai situs penyedia layanan perjalanan (traveling) yang diikuti oleh Tiket.com, Pegipegi.com, dan Booking.com (Similar Web, 2019).

Sebagai website traveling yang memiliki jumlah pengunjung tertinggi, Traveloka perlu memerhatikan kualitas website yang mencakup performansi, keamanan, mobile, dan Search Engine Optimization (SEO). Kualitas website Traveloka memiliki nilai 94, mengalahkan para kompetitornya dengan urutan selanjutnya adalah Booking.com dengan nilai 89, Pegipegi.com dengan nilai 87, dan Ticket.com dengan nilai 69 (Website Grader, 2019).

Meskipun memiliki jumlah pengunjung yang tinggi dan penilaian kualitas website yang tinggi, website Traveloka masih memiliki kekurangan ditandai dengan masih adanya komplain pengguna website yang bisa ditemukan di beberapa media. Hal tersebut dapat dijadikan peluang sebagai bentuk co-creation pada perusahaan Traveloka. Co-creation merupakan langkah kerja sama yang nyata antara perusahaan dengan pelanggan, melalui proses bertukar pikiran / pendapat, untuk menciptakan produk/layanan baru (Midtrans, 2016).

Jika dilihat dari urutan hasil penilaian kualitas website dan jumlah pengunjungnya, Traveloka selalu menduduki posisi pertama, namun terdapat perbedaan posisi pada kompetitornya. Berdasarkan jumlah pengunjungnya urutan kompetitor Traveloka adalah Tiket.com, Pegipegi.com, dan terakhir Booking.com. Berdasarkan hasil penilaian kualitas website urutan kompetitor Traveloka adalah Booking.com, Pegipegi.com, dan terakhir Ticket.com. Hal tersebut menunjukkan bahwa kualitas suatu website tidak mempengaruhi sikap pengguna untuk mengunjungi website. Hal ini bertentangan dengan penelitian terdahulu yang menyatakan bahwa terdapat pengaruh antara kualitas website dengan sikap pengguna.

Sedangkan pengaruh antara sikap pengunjung terhadap minat untuk berpartisipasi dalam online co-creation pada website Traveloka belum dapat dipastikan karena sebelumnya dinyatakan bahwa kualitas suatu website tidak mempengaruhi sikap pengguna untuk mengunjungi website, sehingga perlu dilakukan penelitian lebih lanjut untuk membuktikan pernyataan pada penelitian sebelumnya yang menyatakan terdapat pengaruh antara sikap pengunjung terhadap minat berpartisipasi co-creation adalah benar.

\section{Rumusan Masalah}

Adapun rumusan masalah dalam penelitian ini yaitu untuk menguji atau membuktikan kebenaran dari penelitian sebelumnya yang menyatakan bahwa terdapat pengaruh atau hubungan langsung dan signifikan antara kualitas website (ease of use, 
information, interactivity, dan web design) terhadap sikap pengunjung dan minat berpartisipasi dalam online co-creation pada website Traveloka.

\section{Tujuan Penelitian}

Tujuan dari penelitian ini diantaranya:

1. Mengetahui apakah terdapat pengaruh antara kualitas website Traveloka terhadap sikap pengguna website.

2. Mengetahui apakah terdapat pengaruh antara kualitas website Traveloka terhadap minat berpartisipasi dalam online co-creation.

3. Mengetahui apakah terdapat pengaruh antara sikap pengguna terhadap minat berpartisipasi dalam online co-creation pada website Traveloka.

\section{KAJIAN PUSTAKA \\ Kualitas Website}

Kualitas website merupakan sebuah konsep yang muncul dari kebutuhan akan mengadaptasi konsepsi klasik dari suatu kualitas layanan dan menggunakan dimensi pemodelan SERVQUAL atau service quality (bukti fisik, keandalan, daya tanggap, jaminan, dan empati) yang memungkinkan konsumen berinteraksi secara lebih luas dengan elemen teknologi (Parasuraman \& Grewal, 2000).

\section{Attitude}

Sikap (attitude) adalah cerminan rasa senang, tidak senang, atau biasa-biasa saja (netral) dari seseorang terhadap sesuatu. Sesuatu tersebut bisa berupa benda, kejadian, situasi, orang-orang atau kelompok. Jika rasa yang timbul adalah senang, maka disebut sikap positif, sedangkan rasa tidak senang disebut sikap negatif. Jika tidak timbul perasaan apa-apa disebut sikap netral (Sarwono S. W., 2009).

\section{Co-Creation}

Co-creation merupakan upaya menciptakan nilai pelanggan, dimana perusahaan berfokus pada pelanggan (customer benefit), kompetensi inti pada business domain, dan collaborative network pada business partners. Perusahaan menciptakan nilai pelanggan apabila memiliki kemampuan untuk memberikan keuntungan kepada pelanggan, memiliki kompetensi inti yang mumpuni, dan memiliki rekanan bisnis yang bagus dalam jaringan kolaborasi (Kotler \& Keller, 2016).

\section{Kerangka Pemikiran}

Berdasarkan penelitian sebelumnya dijelaskan bahwa kualitas website memiliki pengaruh positif terhadap sikap, kualitas website juga memiliki pengaruh positif terhadap minat berpartisipasi dalam online co-creation, dan sikap memiliki pengaruh positif terhadap minat berpartisipasi dalam online co-creation. Sikap berperan sebagai mediator antara website dan minat berpartisipasi dalam online co-creation. 


\section{Gambar 1. Kerangka Pemikiran}

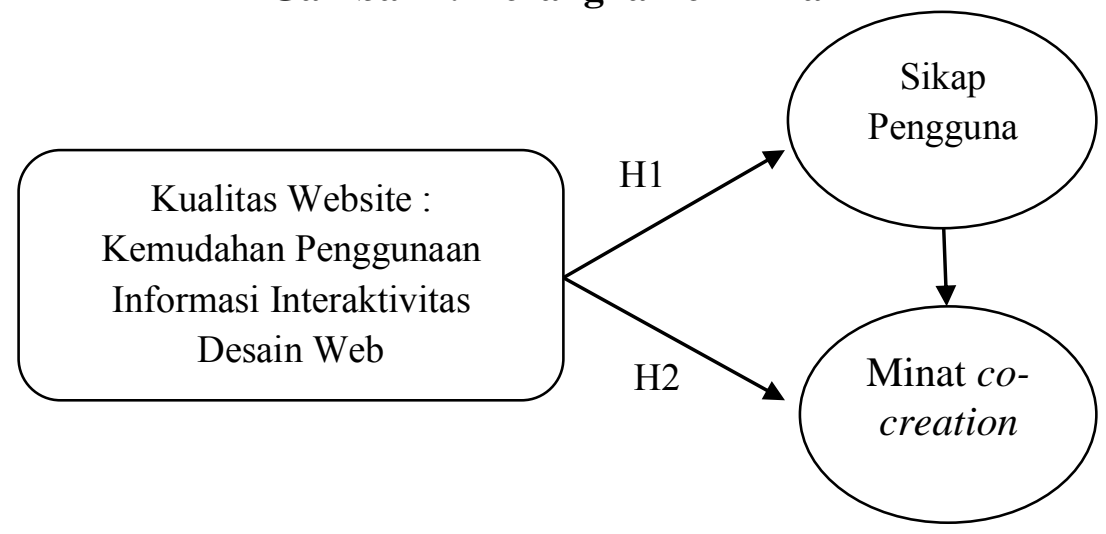

Sumber : Martinez \& Barreto (2017)

\section{Hipotesis Peneliitian}

H1 : Kualitas website Traveloka memiliki pengaruh positif terhadap sikap pengguna website.

$\mathrm{H} 2 \quad$ : Kualitas website Traveloka memiliki pengaruh positif terhadap minat berpartisipasi dalam online co-creation .

H3 : Sikap pengguna website memiliki pengaruh positif terhadap minat berpartisipasi dalam online co-creation pada website Traveloka.

\section{METODE PENELITIAN}

\section{Jenis Penelitian}

Metode yang digunakan dalam penelitian ini adalah metode kuantitatif dengan mengumpulkan data dari responden yang berupa angka, skala maupun grafik yang bisa dihitung dan dianalisis sehingga dapat ditarik suatu kesimpulan terkait pengaruh kualitas website Traveloka terhadap sikap pengguna website dan minat berpartisipasi dalam online co-creation pada website Traveloka.

\section{Tempat, Waktu, dan Subjek Penelitian}

Tempat penelitian bersifat daring karena penyebaran kuisioner dilakukan secara online.

Waktu Penelaksanaan yang digunakan yaitu cross sectional, proses mengobservasi dan mengumpulkan data dilakukan untuk diolah, dianalisis dan ditarik kesimpulan dari suatu fenomena pada satu periode waktu tertentu (Sugiyono, 2016). Periode penyebaran kuesioner dilakukan pada bulan Oktober sampai bulan Desember 2019.

Unit analisis yang diperhitungkan sebagai subjek penelitian ini adalah sampel yang bersifat individu dari suatu populasi tertentu yang merupakan pengunjung website Traveloka dan pernah melakukan transaksi. 


\section{Teknik Pengumpulan Data}

Data sekunder sebagai referensi atau landasan teori dalam penelitian ini bersumber dari berbagai macam literatur seperti jurnal, artikel, dan buku dengan informasi yang relevan sehingga dapat dipelajari, dipahami dan ditarik kesimpulannya.

Data primer pada penelitian ini diperoleh langsung dari hasil jawaban responden melalui kuesioner.

\section{Teknik Analisis Data}

\section{Method of Successive Interval (MSI)}

Skala yang digunakan dalam penelitian ini bersifat ordinal (skala likert), sedangkan teknik yang digunakan dalam analisis data adalah path analysis, dimana data yang diperlukan harus dalam bentuk skala interval, sehingga dibutuhkan transformasi data dari skala ordinal menjadi interval.

2. Analisis Deskriptif

Statistik yang digunakan untuk menganalisa data dengan cara mendeskripsikan atau menggambarkan data yang telah terkumpul.

3. Uji Normalitas

Dilakukan untuk mengetahui bahwa sampel yang digunakan berasal dari populasi yang berdistribusi normal (Sandjojo, 2011).

4. Uji Homogenitas

Dilakukan untuk mengetahui bahwa sampel yang digunakan berasal dari populasi yang memiliki varians yang homogen (Sandjojo, 2011).

5. Uji Signifikansi dan Linieritas

Dilakukan untuk mengetahui bahwa variable-variabel yang dirumuskan dalam model teorik penelitian mempunyai hubungan yang signifikan dan linier (Sandjojo, 2011).

6. Analisis Jalur (Path Analysis)

Analisis jalur atau path analysis adalah teknik dalam menganalisis data untuk mengetahui hubungan sebab akibat yang tejadi pada regresi linier berganda, tidak hanya secara langsung tetapi juga secara tidak langsung melalui variabel antara (Sandjojo, 2011).

Variabel yang digunakan dalam penelitian ini terdiri dari variabel bebas $(\mathrm{X})$ yaitu kualitas website Traveloka dengan sub variabel ease of use (X1), information (X2), interactivity (X3), web design (X4), variabel antara yaitu sikap pengguna, dan variabel terikat $(\mathrm{Z})$ yaitu minat co-creation.

\section{Tabel 1. Operasionalisasi Variabel}

\begin{tabular}{|l|l|c|}
\hline Dimensi & Indikator & Item \\
\hline Ease of Use & $\begin{array}{l}\text { Saya mudah menemukan bagian yang ingin saya lihat dalam } \\
\text { website Traveloka }\end{array}$ & $\mathbf{1}$ \\
\cline { 2 - 3 } & $\begin{array}{l}\text { Website Traveloka memiliki kumpulan kategori yang tertata } \\
\text { dengan baik }\end{array}$ & $\mathbf{2}$ \\
\cline { 2 - 3 } & $\begin{array}{l}\text { Saya dapat mengakses hal yang saya inginkan hanya dengan } \\
\text { beberapa klik }\end{array}$ & $\mathbf{3}$ \\
\hline Information & Informasi mudah saya dapat melalui website Traveloka & $\mathbf{4}$ \\
\cline { 2 - 3 } & Website Traveloka menyediakan informasi yang memadai & $\mathbf{5}$ \\
\hline
\end{tabular}


Lanjutan Tabel 1. Operasionalisasi Variabel

\begin{tabular}{|c|c|c|}
\hline & $\begin{array}{l}\text { Informasi yang tersedia dalam website Traveloka berguna bagi } \\
\text { saya }\end{array}$ & 6 \\
\hline & $\begin{array}{l}\text { Website Traveloka merupakan sumber terpercaya dalam } \\
\text { menyediakan informasi yang saya butuhkan }\end{array}$ & 7 \\
\hline Interactivity & $\begin{array}{l}\text { Website Traveloka merupakan sumber terpercaya dalam } \\
\text { menyediakan informasi yang saya butuhkan }\end{array}$ & 8 \\
\hline & $\begin{array}{l}\text { Saya dapat membagikan pengalaman saya dan menghubungi } \\
\text { pihak Traveloka melalui website Traveloka }\end{array}$ & 9 \\
\hline & $\begin{array}{l}\text { Saya memiliki informasi terkait akses ke jejaring sosial } \\
\text { Traveloka (Facebook/Twitter/Instagram) dari website Traveloka }\end{array}$ & 10 \\
\hline Web Design & Tampilan website Traveloka menarik bagi saya & 11 \\
\hline & Website Traveloka terorganisir dengan baik & 12 \\
\hline & $\begin{array}{l}\text { Website Traveloka menggunakan konten multimedia (teks, } \\
\text { gambar, grafik, video) degan tepat }\end{array}$ & 13 \\
\hline & $\begin{array}{l}\text { Pilihan warna yang digunakan untuk desain website Traveloka } \\
\text { sudah tepat }\end{array}$ & 14 \\
\hline & $\begin{array}{l}\text { Pilihan font yang digunakan untuk desain website traveloka } \\
\text { sudah tepat. }\end{array}$ & 15 \\
\hline Attitude & Website Traveloka adalah website yang bagus & 16 \\
\hline & Saya memiliki reaksi yang positif terhadap website Traveloka & 17 \\
\hline & Saya menyukai website Traveloka & 18 \\
\hline Co-Creation & $\begin{array}{l}\text { Saya tertarik untuk menanyakan informasi lebih lanjut secara } \\
\text { langsung melalui website }\end{array}$ & 19 \\
\hline & $\begin{array}{l}\text { Pengalaman bertransaksi mendorong saya untuk berpartisipasi } \\
\text { dalam membagikan konten atau informasi pada website } \\
\text { Traveloka }\end{array}$ & 20 \\
\hline & $\begin{array}{l}\text { Ada kemungkinan besar bahwa saya kan membagikan konten } \\
\text { atau pendapat saya }\end{array}$ & 21 \\
\hline
\end{tabular}

Sumber : Data Peneliti (2019)

\section{HASIL PENELITIAN DAN PEMBAHASAN}

1. Karakteristik Responden

Tabel 2. Karakteristik Responden

\begin{tabular}{|l|l|c|c|}
\hline \multicolumn{2}{|c|}{ Karakteristik Responden } & $\begin{array}{l}\text { Jumlah } \\
\text { (Orang) }\end{array}$ & $\begin{array}{l}\text { Persentase } \\
(\boldsymbol{\%})\end{array}$ \\
\hline \multirow{3}{*}{ Jenis Kelamin } & Laki-Laki & 215 & 52.2 \\
\cline { 2 - 4 } & Perempuan & 197 & 47.8 \\
\hline \multirow{4}{*}{ Usia } & $<$ 15 Tahun & 1 & 0.2 \\
\cline { 2 - 4 } & 15-64 Tahun & 409 & 99.3 \\
\cline { 2 - 4 } & 64 Tahun & 2 & 0.5 \\
\hline \multirow{4}{*}{ Pekerjaan } & Mahasiswa & 219 & 53.2 \\
\cline { 2 - 4 } & Pegawai & 142 & 34.5 \\
\cline { 2 - 4 } & Wiraswasta / Wirausaha & 19 & 4.6 \\
\cline { 2 - 4 } & Ibu Rumah Tangga & 12 & 2.9 \\
\cline { 2 - 4 } & TNI AD & 8 & 1.9 \\
\hline
\end{tabular}


Lanjutan Tabel 2. Karakteristik Responden

\begin{tabular}{|l|l|c|c|}
\hline \multicolumn{2}{|c|}{ Karakteristik Responden } & $\begin{array}{c}\text { Jumlah } \\
\text { (Orang) }\end{array}$ & $\begin{array}{c}\text { Persentase } \\
(\mathbf{\%})\end{array}$ \\
\hline \multirow{5}{*}{} & Freelancer & 2 & 0.5 \\
\cline { 2 - 4 } & Supervisor & 2 & 0.5 \\
\cline { 2 - 4 } & Polisi & 2 & 0.5 \\
\cline { 2 - 4 } & Pengacara / Advokat & 3 & 0.7 \\
\cline { 2 - 4 } & Pensiunan & 1 & 0.2 \\
\cline { 2 - 4 } & Pelajar & 1 & 0.2 \\
\cline { 2 - 4 } & Dokter Gigi & 1 & 0.2 \\
\hline \multirow{5}{*}{ Pendapatan } & $<$ Rp 1.500.000 & 25 & 6.1 \\
\cline { 2 - 4 } & Rp 1.500.000-Rp 2.500.000 & 52 & 12.6 \\
\cline { 2 - 4 } & Rp 2.500.001 - Rp 3.500.000 & 92 & 22.3 \\
\cline { 2 - 4 } & Rp 3.500.000 & 243 & 59 \\
\hline Domisili (Pulau) & Jawa & 342 & 83 \\
\cline { 2 - 4 } & Sumatera & 2 & 12.13 \\
\cline { 2 - 4 } & Kalimanta & 1 & 0.4 \\
\cline { 2 - 4 } & Sulawesi & 6 & 0.2 \\
\hline & Bali & 206 \\
\hline & Papua & 1.45 \\
\hline
\end{tabular}

Sumber : Hasil Penelitian, diolah (2019)

2. Uji Validitas dan Reliabilitas

Tabel 3. Uji Validitas

\begin{tabular}{|c|c|c|c|c|}
\hline Variabel & $\begin{array}{c}\text { Sub } \\
\text { Variabel }\end{array}$ & No. Item & Nilai Korelasi & Status \\
\hline \multirow{16}{*}{$\begin{array}{l}\text { Kualitas } \\
\text { Website } \\
\text { Traveloka }\end{array}$} & \multirow[t]{4}{*}{ Ease of Use } & 1 & 0.136 & Tidak Valid \\
\hline & & 2 & 0.351 & Valid \\
\hline & & 3 & 0.806 & Valid \\
\hline & & 4 & 0.714 & Valid \\
\hline & \multirow[t]{4}{*}{ Information } & 5 & 0.646 & Valid \\
\hline & & 6 & 0.705 & Valid \\
\hline & & 7 & 0.616 & Valid \\
\hline & & 8 & 0.690 & Valid \\
\hline & \multirow[t]{3}{*}{ Interactivity } & 9 & 0.617 & Valid \\
\hline & & 10 & 0.807 & Valid \\
\hline & & 11 & 0496 & Valid \\
\hline & \multirow[t]{5}{*}{ Web Design } & 12 & 0.668 & Valid \\
\hline & & 13 & 0.747 & Valid \\
\hline & & 14 & 0.738 & Valid \\
\hline & & 15 & 0.613 & Valid \\
\hline & & 16 & 0.763 & Valid \\
\hline \multirow{3}{*}{\multicolumn{2}{|c|}{ Sikap Pengguna Website }} & 17 & 0.769 & Valid \\
\hline & & 18 & 0.849 & Valid \\
\hline & & 19 & 0.801 & Valid \\
\hline
\end{tabular}


Lanjutan Tabel 3. Uji Validitas

\begin{tabular}{|l|c|c|c|}
\hline & No. Item & Nilai Korelasi & Status \\
\hline \multirow{2}{*}{$\begin{array}{l}\text { Minat dalam online co- } \\
\text { creation }\end{array}$} & $\mathbf{2 0}$ & $\mathbf{0 . 8 4 0}$ & Valid \\
\cline { 2 - 4 } & $\mathbf{2 1}$ & $\mathbf{0 . 7 7 4}$ & Valid \\
\cline { 2 - 4 } & $\mathbf{2 2}$ & $\mathbf{0 . 6 8 3}$ & Valid \\
\hline
\end{tabular}

Sumber : Hasil Penelitian, diolah (2019)

Berdasarkan hasil uji validitas pada Tabel 3 angka korelasi antar item pada item 1 bernilai < 0,3 yaitu sebesar 0,136 maka dinyatakan tidak valid, sehingga item 1 dengan pernyataan "website Traveloka mudah dicari atau ditemukan" dari variabel ease of use tidak dilanjutkan dalam kuesioner.

Tabel 4. Uji Reliabilitas

\begin{tabular}{|c|c|c|}
\hline Cronbach's Alpha & $\begin{array}{l}\text { Cronbach's Alpha Based } \\
\text { on Standardized Items }\end{array}$ & N of Items \\
\hline 0.758 & 0.950 & 23 \\
\hline
\end{tabular}

Sumber : Hasil Penelitian, diolah (2019)

Berdasarkan hasil uji reliabilitas pada Tabel 4 menunjukkan angka Cronbach's Alpha bernilai positif yaitu 0,758 dan > 0,6, sehingga dapat disimpulkan bahwa seluruh item pernyataan dalam penelitian ini adalah reliabel.

Analisis Deskriptif

Tabel 5. Analisis Deskriptif

\begin{tabular}{|c|c|c|}
\hline Variabel & No. Item & $\%$ \\
\hline \multirow{3}{*}{ Ease of Use $\left(X_{1}\right)$} & Item 1 & 84.70 \\
\hline & Item 2 & 84.17 \\
\hline & Item 3 & 81.99 \\
\hline \multirow{4}{*}{ Information $\left(X_{2}\right)$} & Item 4 & 87.86 \\
\hline & Item 5 & 86.94 \\
\hline & Item 6 & 87.71 \\
\hline & Item 7 & 84.66 \\
\hline \multirow{3}{*}{ Interactivity $\left(X_{3}\right)$} & Item 8 & 75.04 \\
\hline & Item 9 & 75.29 \\
\hline & Item 10 & 78.30 \\
\hline \multirow{5}{*}{ Web Design $\left(W_{4}\right)$} & Item 11 & 79.85 \\
\hline & Item 12 & 85.57 \\
\hline & Item 13 & 82.91 \\
\hline & Item 14 & 82.96 \\
\hline & Item 15 & 82.52 \\
\hline \multirow{3}{*}{ Attitude (Y) } & Item 16 & 81.55 \\
\hline & Item 17 & 81.65 \\
\hline & Item 18 & 78.88 \\
\hline \multirow{3}{*}{ Co-Creation (Z) } & Item 19 & 69.85 \\
\hline & Item 20 & 73.10 \\
\hline & Item 21 & 75.45 \\
\hline
\end{tabular}

Sumber : Hasil Penelitian, diolah (2019) 
3. Uji Normalitas

Tabel 6. One-Sample Kolmogorov-Smirnov Test Variabel Attitude

\begin{tabular}{|c|c|c|}
\hline \multicolumn{2}{|c|}{} & Unstandardized Residual \\
\hline $\mathrm{N}$ & Mean & 412 \\
\hline \multirow{2}{*}{$\begin{array}{c}\text { Normal } \\
\text { Parameters }\end{array}$} & a,b \\
\cline { 2 - 3 } Most Extreme & Std. Deviation & 0,0000000 \\
\cline { 2 - 3 } Differences & Absolute & 0,33114083 \\
\cline { 2 - 3 } & Positive & 0,043 \\
\hline \multicolumn{2}{|r|}{ Test Statistic } & 0,043 \\
\hline \multicolumn{2}{|r|}{ Negative } & $-0,042$ \\
\hline \multicolumn{2}{|r|}{ Asymp. Sig. (2-tailed) } & 0,043 \\
\hline
\end{tabular}

Sumber : Hasil Penelitian, diolah (2019)

Hasil uji normalitas melalui One-Sample Kolmogorov-Smirnov Test untuk variabel kualitas website (X) terhadap variabel sikap (Y) diperoleh nilai Asymp. Sig. (2-tailed) sebesar 0,071, sehingga disimpulkan bahwa data berdistribusi normal karena nilai Asymp. Sig (2-tailed) > 0,05.

Tabel 7. One-Sample Kolmogorov-Smirnov Test Variabel Co-Creation

\begin{tabular}{|c|c|c|}
\hline & & Unstandardized Residual \\
\hline \multicolumn{2}{|l|}{$\mathrm{N}$} & 412 \\
\hline \multirow{2}{*}{$\begin{array}{c}\text { Normal } \\
\text { Parameters }^{\mathrm{a}, \mathrm{b}}\end{array}$} & Mean & 0,0000000 \\
\hline & Std. Deviation & 0,54193482 \\
\hline \multirow{3}{*}{$\begin{array}{l}\text { Most Extreme } \\
\text { Differences }\end{array}$} & Absolute & 0,037 \\
\hline & Positive & 0,036 \\
\hline & Negative & $-0,037$ \\
\hline \multicolumn{2}{|c|}{ Test Statistic } & 0,037 \\
\hline \multicolumn{2}{|c|}{ Asymp. Sig. (2-tailed) } &, $186^{\mathrm{c}}$ \\
\hline
\end{tabular}

Sumber : Hasil Penelitian, diolah (2019)

Hasil uji normalitas melalui One-Sample Kolmogorov-Smirnov Test untuk variabel kualitas website $(\mathrm{X})$ terhadap variabel co-creation $(\mathrm{Z})$ diperoleh nilai Asymp. Sig. (2-tailed) sebesar 0,186. Berdasarkan hasil tersebut dapat disimpulkan bahwa data berdistribusi normal karena nilai Asymp. Sig (2-tailed) atau nilai P > 0,05 .

4. Uji Homogenitas

Tabel 8. Uji Homogenitas Variabel Attitude

\begin{tabular}{|c|c|c|c|c|c|}
\hline & & Levene Stat. & $d f 1$ & $d f 2$ & Sig. \\
\hline \multirow[t]{4}{*}{ Attitude } & Based on Mean & 0,959 & 12 & 398 & 0,488 \\
\hline & Based on Median & 0,731 & 12 & 398 & 0,721 \\
\hline & $\begin{array}{l}\text { Based on Median } \\
\text { and with adjusted } \\
d f\end{array}$ & 0,731 & 12 & 382,948 & 0,721 \\
\hline & $\begin{array}{l}\text { Based on } \\
\text { trimmed mean }\end{array}$ & 0,995 & 12 & 398 & 0,452 \\
\hline
\end{tabular}

Sumber : Hasil Penelitian, diolah (2019) 
Hasil uji homogenitas untuk variabel kualitas website (X) terhadap variabel sikap (Y), hasilnya menunjukkan nilai signifikansi untuk mean, median, median dan adjusted $d f$, dan trimmed mean masing-masing $>0,05$. Artinya varians dari populasi data tersebut adalah sama (homogen).

Tabel 9. Uji Homogenitas Variabel Co-Creation

\begin{tabular}{|l|l|c|c|c|c|}
\hline & & $\begin{array}{c}\text { Levene } \\
\text { Stat. }\end{array}$ & df1 & df2 & Sig. \\
\hline \multirow{3}{*}{ Co-Creation } & Based on Mean & 1,581 & 13 & 395 & 0,088 \\
\cline { 2 - 6 } & Based on Median & 1,331 & 13 & 395 & 0,192 \\
\cline { 2 - 6 } & $\begin{array}{l}\text { Based on Median and } \\
\text { with adjusted df }\end{array}$ & 1,331 & 13 & 379,926 & 0,192 \\
\cline { 2 - 6 } & Based on trimmed mean & 1,545 & 13 & 395 & 0,099 \\
\hline
\end{tabular}

Sumber : Hasil Penelitian, diolah (2019)

Hasil uji homogenitas untuk variabel kualitas website (X) terhadap variabel cocreation $(\mathrm{Z})$ menunjukkan nilai signifikansi untuk mean, median, median dan adjusted $d f$, dan trimmed mean masing-masing $>0,05$. Artinya varians dari populasi data tersebut adalah sama (homogen).

\section{Uji Signifikansi dan Linieritas}

Tabel 10. Uji F (ANOVA) Terhadap Variabel Attitude

\begin{tabular}{|c|c|c|c|c|c|}
\hline \multicolumn{2}{|l}{} & $\begin{array}{c}\text { Standardized } \\
\text { Coefficients } \\
\text { Beta }\end{array}$ & $\mathbf{t}$ & Sig. \\
\hline (Constant) & 0,450 & 0,177 & & 2,541 & 0,011 \\
\hline Ease of Use & 0,232 & 0,048 & 0,224 & 4,869 & 0,000 \\
\hline Information & $-0,006$ & 0,044 & $-0,006$ & $-0,131$ & 0,896 \\
\hline Interactivity & 0,115 & 0,040 & 0,118 & 2,849 & 0,005 \\
\hline Web Design & 0,532 & 0,046 & 0,521 & 11,488 & 0,000 \\
\hline
\end{tabular}

Sumber : Hasil Penelitian, diolah (2019)

Nilai Sig. yang diperoleh untuk variabel ease of use, interactivity, dan web design adalah $0,000,0,005$, dan $0,000<0,05$, artinya terdapat pengaruh yang signifikan antara variabel ease of use, interactivity, dan web design dengan variabel sikap. Nilai variabel information adalah $0,896>0,05$, artinya tidak terdapat pengaruh yang signifikan antara variabel information dengan variabel sikap.

Tabel 11. Uji F (ANOVA) Terhadap Variabel Co-Creation

\begin{tabular}{|l|c|c|c|c|c|}
\hline \multicolumn{2}{|l|}{} & $\begin{array}{c}\text { Standardized } \\
\text { Coefficients } \\
\text { Beta }\end{array}$ & t & Sig. \\
\hline (Constant) & 0,868 & 0,223 & & 3,884 & 0,000 \\
\hline Ease of Use & 0,083 & 0,060 & 0,077 & 1,384 & 0,167 \\
\hline Information & $-0,036$ & 0,056 & $-0,033$ & $-0,635$ & 0,526 \\
\hline Interactivity & 0,379 & 0,051 & 0,370 & 7,411 & 0,000 \\
\hline Web Design & 0,313 & 0,058 & 0,292 & 5,353 & 0,000 \\
\hline
\end{tabular}

Sumber : Hasil Penelitian, diolah (2019) 
Nilai Sig. untuk variabel ease of use dan information adalah 0,167 dan 0,526 > 0,05 , artinya tidak terdapat pengaruh yang signifikan antara variabel ease of use dan information dengan variabel co-creation. Nilai variabel interactivity dan web design adalah 0,000 dan $0,000<0,05$, artinya terdapat pengaruh yang signifikan antara variabel interactivity dan web design dengan variabel co-creation.

Tabel 12. Uji Linieritas

\begin{tabular}{|c|l|l|}
\hline Variabel Dependen & \multicolumn{1}{|c|}{ Variabel Independen } & Nilai Linearity Sig. \\
\hline \multirow{4}{*}{ Attitude } & Ease of Use & 0,000 \\
\cline { 2 - 3 } & Information & 0,000 \\
\cline { 2 - 3 } & Interactivity & 0,000 \\
\cline { 2 - 3 } & Web Design & 0,000 \\
\hline \multirow{4}{*}{ Co-Creation } & Ease of Use & 0,000 \\
\cline { 2 - 3 } & Information & 0,000 \\
\cline { 2 - 3 } & Interactivity & 0,000 \\
\cline { 2 - 3 } & Web Design & 0,000 \\
\hline
\end{tabular}

Sumber : Hasil Penelitian, diolah (2019)

Nilai Linearity Sig. variabel dependen attitude dengan variabel independen ease of use, information, interactivity dan web design adalah $<0,05$, artinya terdapat hubungan yang linier dan signifikan. Nilai Linearity Sig. variabel dependen cocreation dengan variabel independen ease of use, information, interactivity dan web design adalah $<0,05$. Artinya terdapat hubungan yang linier dan signifikan.

Uji Analisis Jalur

Tabel 13. Model Summary Variabel Attitude

\begin{tabular}{|c|c|c|c|c|}
\hline Model & R & R Square & $\begin{array}{c}\text { Adjusted R } \\
\text { Square }\end{array}$ & $\begin{array}{c}\text { Std. Error of } \\
\text { the Estimate }\end{array}$ \\
\hline 1 &, $756^{\mathrm{a}}$ & 0,572 & 0,568 & 0,50692 \\
\hline
\end{tabular}

Sumber : Hasil Penelitian, diolah (2019)

Nilai R Square pada tabel Model Summary adalah 0,572, hal ini menunjukkan bahwa pengaruh kualitas website terhadap sikap adalah sebesar 57,2\% dan sisanya $42,8 \%$ berasal dari variabel lain yang tidak dimasukkan dalam penelitian ini.

Tabel 14. Tabel Koefisien Variabel Attitude

\begin{tabular}{|l|c|c|c|c|c|}
\hline \multicolumn{2}{|l|}{} & $\begin{array}{c}\text { Standardized } \\
\text { Coefficients } \\
\text { Beta }\end{array}$ & t & Sig. \\
\hline (Constant) & 0,450 & 0,177 & & 2,541 & 0,011 \\
\hline Ease of Use & 0,232 & 0,048 & 0,224 & 4,869 & 0,000 \\
\hline Information & $-0,006$ & 0,044 & $-0,006$ & $-0,131$ & 0,896 \\
\hline Interactivity & 0,115 & 0,040 & 0,118 & 2,849 & 0,005 \\
\hline Web Design & 0,532 & 0,046 & 0,521 & 11,488 & 0,000 \\
\hline
\end{tabular}

Sumber : Hasil Penelitian, diolah (2019)

Analisis jalur antara variabel sikap dan variabel kualitas website, diketahui nilai signifikansi untuk variabel ease of use, interactivity, dan web design masing-masing adalah $0,000,0,005$, dan $0,000<0,05$, artinya variabel ease of use, interactivity, dan 
web design berpengaruh secara signifikan terhadap variabel sikap. Sedangkan nilai signifikansi untuk variabel information $0,896>0,05$, artinya variabel information tidak berpengaruh secara signifikan terhadap variabel sikap.

Berdasarkan nilai Standardized Coefficients Beta, nilai untuk koefisien jalur kualitas website terhadap sikap adalah sebagai berikut:

Gambar 2. Model Analisis Jalur Terhadap Variabel Attitude

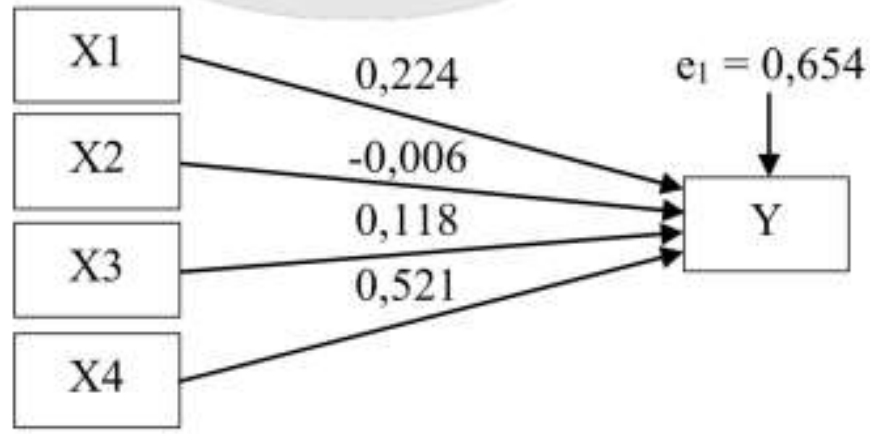

Sumber : Hasil Penelitian, diolah (2019)

Nilai koefisien jalur variabel ease of use terhadap sikap adalah 0,224, variabel information terhadap sikap adalah -0,006, variabel interactivity terhadap sikap adalah 0,118 , dan variabel web design terhadap sikap adalah 0,521. Nilai e1 diperoleh dari $\sqrt{ }(1-0,572)$ hasilnya adalah 0,654 .

Tabel 15. Model Summary Variabel Co-Creation

\begin{tabular}{|c|c|c|c|c|}
\hline Model & $\mathbf{R}$ & R Square & $\begin{array}{c}\text { Adjusted R } \\
\text { Square }\end{array}$ & $\begin{array}{c}\text { Std. Error of } \\
\text { the Estimate }\end{array}$ \\
\hline 1 &, $652^{\mathrm{a}}$ & 0,425 & 0,418 & 0,61671 \\
\hline
\end{tabular}

Sumber : Hasil Penelitian, diolah (2019)

Nilai R Square pada tabel Model Summary adalah 0,425, hal ini menunjukkan bahwa kontribusi atau pengaruh kualitas website melalui sikap terhadap co-creation adalah sebesar $42,5 \%$ dan sisanya $57,5 \%$ berasal dari variabel lain yang tidak dimasukkan dalam penelitian ini.

Tabel 16. Tabel Koefisien Variabel Co-Creation

\begin{tabular}{|l|c|c|c|c|c|}
\hline \multicolumn{2}{|l|}{} & $\begin{array}{c}\text { Standardized } \\
\text { Coefficients } \\
\text { Beta }\end{array}$ & t & Sig. \\
\hline (Constant) & 0,713 & 0,217 & & 3,287 & 0,001 \\
\hline Ease of Use & 0,004 & 0,060 & 0,003 & 0,060 & 0,953 \\
\hline Information & $-0,034$ & 0,054 & $-0,031$ & $-0,622$ & 0,534 \\
\hline Interactivity & 0,339 & 0,050 & 0,331 & 6,819 & 0,000 \\
\hline Web Design & 0,130 & 0,065 & 0,122 & 2,008 & 0,045 \\
\hline Attitude & 0,344 & 0,060 & 0,328 & 5,700 & 0,000 \\
\hline
\end{tabular}

Sumber : Hasil Penelitian, diolah (2019) 
Berdasarkan tabel koefisien analisis jalur antara variabel dependen co-creation dan variabel independen kualitas website dengan variabel antara sikap, diketahui bahwa nilai signifikansi untuk variabel interactivity, web design, dan attitude masingmasing adalah 0,000, 0,045 dan 0,000 $<0,05$, artinya variabel interactivity, web design, dan attitude berpengaruh secara signifikan terhadap variabel co-creation. Sedangkan nilai signifikansi untuk variabel ease of use dan information masingmasing adalah 0,953 dan 0,534>0,05, artinya variabel ease of use dan information tidak berpengaruh secara signifikan terhadap variabel co-creation.

Berdasarkan nilai Standardized Coefficients Beta, nilai untuk koefisien jalur kualitas website terhadap co-creation melalui variabel sikap adalah sebagai berikut:

Gambar 3. Model Analisis Jalur Terhadap Variabel Co-Creation

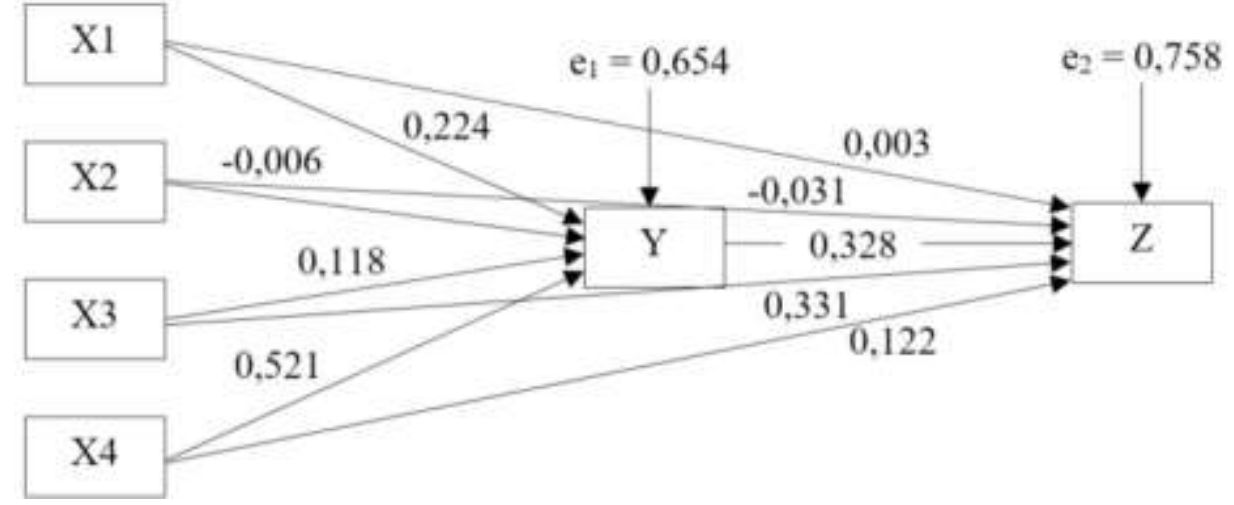

Sumber : Hasil Penelitian, diolah (2019)

Nilai koefisien jalur variabel ease of use terhadap co-creation adalah 0,003 , variabel information terhadap co-creation adalah $-0,031$, variabel interactivity terhadap co-creation adalah 0,331 , dan variabel web design terhadap co-creation adalah 0,122 dengan nilai koefisien jalur variabel antara (sikap) terhadap co-creation adalah 0,328. Nilai e2 diperoleh dari $\sqrt{ }(1-0,425)$ hasilnya adalah 0,758 .

\section{Uji Hipotesis dan Kesimpulan Analisis Jalur (Path Analysis)}

Analisis pengaruh variabel ease of use terhadap co-creation melalui sikap secara langsung adalah sebesar 0,003 sedangkan pengaruh tidak langsung adalah sebesar 0,0734 dari hasil perkalian nilai beta variabel ease of use terhadap sikap $(0,224)$ dengan nilai beta variabel sikap terhadap co-creation $(0,328)$. Pengaruh total $\mathrm{X} 1$ terhadap $\mathrm{Z}$ adalah $0,003+0,0734=0,0764$. Nilai pengaruh langsung $0,003<$ 0,0734 pengaruh tidak langsung, sehingga disimpulkan bahwa secara tidak langsung $\mathrm{X} 1$ memiliki pengaruh signifikan terhadap Z melalui Y.

Analisis pengaruh variabel information terhadap co-creation melalui sikap secara langsung adalah sebesar -0,031 sedangkan pengaruh tidak langsung adalah sebesar -0,0019 dari hasil perkalian nilai beta variabel information terhadap sikap ($0,006)$ dengan nilai beta variabel sikap terhadap co-creation $(0,328)$. Pengaruh total $\mathrm{X} 2$ terhadap $\mathrm{Z}$ adalah $-0,031(-0,0019)=-0,0329$. Nilai pengaruh langsung $-0,031$ dan pengaruh tidak langsung -0,0019 keduanya bernilai negatif, sehingga disimpulkan bahwa X2 tidak memiliki pengaruh signifikan baik secara langsung maupun tidak lagsung terhadap $\mathrm{Z}$ melalui $\mathrm{Y}$. 
Analisis pengaruh variabel interactivity terhadap co-creation melalui sikap secara langsung adalah sebesar 0,331 sedangkan pengaruh tidak langsung adalah sebesar 0,0387 dari hasil perkalian nilai beta variabel interactivity terhadap sikap $(0,118)$ dengan nilai beta variabel sikap terhadap co-creation $(0,328)$. Pengaruh total $\mathrm{X} 3$ terhadap $\mathrm{Z}$ adalah $0,331+0,0387=0,3697$. Nilai pengaruh langsung $0,331>$ 0,0387 pengaruh tidak langsung, sehingga disimpulkan bahwa secara langsung X3 memiliki pengaruh signifikan terhadap $\mathrm{Z}$ melalui $\mathrm{Y}$.

Analisis pengaruh variabel web design terhadap co-creation melalui sikap secara langsung adalah sebesar 0,122 sedangkan pengaruh tidak langsung adalah sebesar 0,1708 dari hasil perkalian nilai beta variabel web design terhadap sikap $(0,521)$ dengan nilai beta variabel sikap terhadap co-creation $(0,328)$. Pengaruh total $\mathrm{X} 4$ terhadap $\mathrm{Z}$ adalah $0,1220,1708=0,2928$. Nilai pengaruh langsung $0,122<0,1708$ pengaruh tidak langsung, sehingga disimpulkan bahwa secara tidak langsung $X 4$ memiliki pengaruh signifikan terhadap $\mathrm{Z}$ melalui $\mathrm{Y}$.

Variabel ease of use (X1) dan web design (X4) memiliki pengaruh signifikan secara tidak langsung, variabel interactivity (X3) memiliki pengaruh signifikan secara langsung, sedangkan variabel information (X2) tidak memiliki pengaruh signifikan baik secara langsung maupun tidak lagsung terhadap variabel co-creation $(\mathrm{Z})$ melalui $\operatorname{sikap}(\mathrm{Y})$.

\section{KESIMPULAN DAN SARAN \\ Kesimpulan}

Berdasarkan pengujian analisis jalur antara variabel dependen sikap (attitude) dan variabel independen kualitas website, disimpulkan bahwa variabel ease of use (X1), interactivity (X3), dan web design (X4) berpengaruh secara signifikan terhadap sikap (Y) sedangkan variabel information (X2) tidak berpengaruh secara signifikan terhadap variabel sikap (Y).

Berdasarkan pengujian analisis jalur antara variabel dependen co-creation dan variabel independen kualitas website dengan variabel antara sikap, disimpulkan bahwa: ariabel ease of use (X1) dan web design (X4) memiliki pengaruh signifikan secara tidak langsung terhadap co-creation $(\mathrm{Z})$ melalui sikap $(\mathrm{Y})$.

Variabel information (X2) tidak memiliki pengaruh signifikan baik secara langsung maupun tidak lagsung terhadap co-creation $(\mathrm{Z})$ melalui sikap (Y).

Variabel interactivity (X3) memiliki pengaruh signifikan secara langsung terhadap co-creation (Z) melalui sikap (Y).

\section{Saran}

Berdasarkan hasil penelitian yang telah dilakukan terkait pengaruh kualitas website Traveloka terhadap sikap pengguna dan minat berpartisipasi dalam online cocreation adapun saran yang penulis ajukan bagi perusahaan Traveloka yaitu Traveloka perlu meningkatkan kualitas website khususnya untuk variabel ease of use dengan menciptakan shortcut sebagai upaya meningkatkan kemudahan dalam menemukan bagian yang ingin dilihat dalam website Traveloka, interactivity dengan menyediakan link yang terhubung secara otomatis sebagai upaya dalam meningkatkan informasi terkait akses ke jejaring sosial Traveloka (Facebook/Twitter/ Instagram) dari website 
Traveloka, dan web design dengan memerhatikan pilihan warna untuk desain website Traveloka karena memiliki pengaruh yang signifikan terhadap variabel co-creation melalui sikap pengguna baik secara langsung maupun tidak langsung.

Berdasarkan hasil penelitian, penulis merekomendasikan saran bagi penelitian selanjutnya diantaranya :

Keterbatasan dalam penelitian ini adalah waktu pengumpulan data yang singkat sehingga peneliti mendapatkan responden yang tidak merata dan didominasi dari Pulau Jawa khususnya Kota Bandung sehingga peneliti menyarankan untuk lebih menyebarkan ke kota-kota lain yang ada di seluruh Indonesia.

Instrumen yang digunakan dalam penelitian ini berupa kuesioner pernyataan yang diukur menggunakan skala Likert dan data yang berskala ordinal. Peneliti menyarankan penelitian selanjutnya tidak hanya menggunakan kuesioner tetapi melakukan wawancara tatap muka untuk memperoleh jawaban yang lebih mendalam serta masukan dari responden.

Penelitian ini belum komprehensif karena hanya melihat pengaruh terhadap cocreation perusahaan Traveloka dari segi kualitas website melalui sikap pengguna, maka untuk kebutuhan penelitian selanjutnya jika berminat meneliti menggunakan pendekatan output dapat meneliti dari segi produk atau jasa yang dihasilkan.

\section{DAFTAR PUSTAKA}

HubSpot, I. 2019. Website Grader. Diambil kembali dari Website Grader: https://website.grader.com/

Kotler, P., \& Keller, K. L. 2016. Marketing Management, 15th Edition. New Jersey: Pearson Pretice Hall, Inc.

Martinez, S. C., \& Barreto, J. J. 2017. Destination Website Quality, Users' Attitudes and the Willingness to Participate in Online Co-Creation Experiences. European Journal of Management and Business Economics: Vol 27 No. 1, 2018, 26-41.

Midtrans. 2016. Marketing Strategy. Diambil kembali dari midtrans: https://blog.midtrans.com/manfaatkan-customer-co-creation-untuk-mendoronginovasi/

Parasuraman, A., \& Grewal, D. 2000. The Impact of Technology on the Quality-ValueLoyalty Chain: A Research Agenda. Journal of the Academy of Marketing Science, 168-170.

Sandjojo, N. 2011. Metode Analisis Jalur (Path Analysis) dan Aplikasinya. Jakarta: Pustaka Sinar Harapan.

Sarwono, S. W. 2009. Pengantar Psikologi Umum. Depok: Rajawali Pers.

Similar Web. 2019. Website Traveloka. Diambil kembali dari

Similar Web: https://www.similarweb.com/website/traveloka.com Sugiyono. (2016). Metodologi Penelitian Kuantitatif, Kualitatif, dan R\&D. Bandung: Alfabeta. 